\title{
Growth and Yield of Common Bean (Phaseolus Vulgaris L.) in Response to Rhizobium Inoculation, Nitrogen and Molybdenum Fertilization
}

\author{
Elkhatib, H.A. ${ }^{1}$
}

\begin{abstract}
Two field trials were carried out in two successive growing seasons of 2006 and 2007 at Elbehara Governerate - Faculty of Agriculture to study the combination effects of seed inoculation (with Rhizobium and without), nitrogen fertilization with $(0,48,96 \mathrm{~kg} \mathrm{~N} / \mathrm{ha})$ and foliar molybdenum application( $(0$ and $30 \mu \mathrm{g} \mathrm{Mo/l}$ as sodium molybdate) on plant height, branch number, plant fresh weight, plant dry weight, average number of green pods per plant and green pods yield $\mathrm{ha}^{-1}$ as well as nitrogen and molybdenum contents in leaves of bean plants Giza3.

The highest values of all investigated parameters were obtained with a combination of seed inoculation, molybdenum application and nitrogen fertilization of 96 kg N/ha. Polynomial quadratic models were developed and used to describe green pods yield responses. Four polynomial equations were established to express the relationship among green pods yield and application rate of $\mathbf{N}$ fertilizer, molybdenum fertilization and Rhizobium inoculation for each season. The calculated yields in the two seasons closely approximate experimental yields as evidenced by the highly significant value of coefficient of determination $\left(\mathbf{R}^{2}\right)$.
\end{abstract}

\section{INTRODUCTION}

Legume crops are not only used as human diet but also for improving soil fertility through biological nitrogen fixation. Among the grain legumes, common bean (Phaseolus vulgaris) is the most important pulse crop in the world .It is an important source of calories, proteins, dietary fibers, minerals and vitamins for millions of people in both developing and developed countries (Consideine, 1992). Egypt is the main exporter of green beans; therefore the expansion in green bean cultivation has exhibited impressive growth during the past several years with a cultivated area of 21.3 thousand hectare with a production of 215 thousand tones of green beans (FAO Statistics, 2007). Beans are capable of fixing atmospheric nitrogen through Rhizobium species living in root nodules. However, poor nodulation of beans under Egyptian agro-ecological conditions is considered the major cause of its lower yield. Inoculation of beans with Rhizobium increased plant height, leaf area, photosynthetic rate and dry matter production (Thakur and Panwar, 1995). Brar and Lal (1991) found an increase yield of mungbean with inoculation of Rhizobium. Also Srivastava et al. (1998) reported that inoculation of pea seeds with Rhizobium leguminosarum gave maximum pod yield of pea. On the other hand Solaiman and Khondaker (2002) stated that maximum green pod yield of $30.78 \mathrm{~g} /$ plant $(111 \%$ increases over uninoculated control) of pea was obtained when plants were inoculated with Rhizobium strains.

Molybdenum (Mo) is an essential micronutrient for plants, bacteria and animals. Molybdenum is directly related to metabolic function of nitrogen in the plant through nitrate reductase enzyme that reduces the nitrate to nitrite, and this the first step of the incorporation of nitrogen to proteins (Marschner 1995). Molybdenum also participates as co - factor of nitrogenase, responsible for biological nitrogen fixation. Jongruaysup et al. (1993) stated that crops developing symbiosis with rhizobium bacteria had increased molybdenum requirements. Deficiency of this element causes a reduction of nodulation and nitrogen fixation. Chahal and Chahal (1991) claimed that foliar applications of molybdenum stimulated nodulation and biological nitrogen fixation, thus increasing the legume yield.

These investigations aimed to study the effect of seed inoculation with Rhizobium, nitrogen fertilization and foliar nutrition with molybdenum on growth and yield of common bean.

\section{MATERIAL AND METHODS}

Two experiments were conducted in two successive growing seasons of 2006 and 2007 at Elbehara Governerate - Faculty of Agriculture, Alexandria University. Soil chemical and physical properties of the experimental soil were determined according to the methods reported by Page et al. (1982). The main chemical characteristics of the two soils are summarized as follows : $\mathrm{N} 0.17$ and $0.15 \%, \mathrm{P} 0.06$ and $0.065 \%, \mathrm{~K}$ 0.13 and $0.12 \%, \mathrm{pH} 7.8$ and 7.85 and, Mo 0.142 and $0.134 \mathrm{ppm}$ in the seasons of 2006 and 2007 respectively.

The experimental layout was a split- split plot system in a randomized complete blocks design with three replications. Rhizobium inoculations were

${ }^{1}$ Horticulture Dept. Faculty of Agriculture,

Damanhour Branch, Alex. Univ.

Received June1, 2009, Accepted June30, 2009 
arranged in the main plots, Inorganic nitrogen rates were assigned to sub-plots and molybdenum rates were

distributed in the sub-sub plots. The plots were formed by three rows of $5 \mathrm{~m}$ length, and $0.7 \mathrm{~m}$ width. Common bean (Phaseolus vulgaris L.) Giza-3 cultivar was used in both years of investigations (summer of 2006 and 2007 seasons).

Each experiment was established with 12 variants represented the combinations among; seed inoculation (with and without nitrogen fixing bacteria of genus Rhizobium), three inorganic nitrogen fertilizer rates $(0$, 48 and $96 \mathrm{~kg} \mathrm{~N} \mathrm{ha}^{-1}$ and two molybdenum rates $(0$ and $30 \mu \mathrm{g} \mathrm{Mo/l)}$ as sodium molybdate.

Bean seed inoculations were done with the symbiotic N-fixing bacteria of genus Rhizobium by coating the seeds at the rate of $20 \mathrm{gms}$ of Oqadin $/ \mathrm{kg}$ of seeds using staking substance (Arabic gum 5\%) just before sowing and then were directly sown on one side of the row at $15 \mathrm{~cm}$ intra-raw spacing. Nitrogen was applied by hand as ammonium sulphate $(20.5 \% \mathrm{~N})$ at two equal doses; 3 and 5 weeks after sowing. Molybdenum foliar fertilization was applied at 15 and 25 days after plant emergence as sodium molybdate (30 $\mu \mathrm{g} \mathrm{Mo} / \mathrm{l}$ as sodium molybdate $\left(\mathrm{Na}_{2} \mathrm{MoO}_{4} \cdot 2 \mathrm{H}_{2} \mathrm{O}\right)$. Phosphorus and potassium fertilizations were also applied in doses of $72 \mathrm{~kg} \mathrm{P}_{2} \mathrm{O}_{5} / \mathrm{ha}$ and $115 \mathrm{~kg} \mathrm{~K}_{2} \mathrm{O} / \mathrm{ha}$ as calcium super phosphate $\left(15.5 \% \quad \mathrm{P}_{2} \mathrm{O}_{5}\right)$ and potassium sulphate $\left(48 \% \mathrm{~K}_{2} \mathrm{O}\right)$ respectively.

The data of vegetative growth characters were recorded using five random chosen plants from each treatment, 60 days after seed sowing. The following measurements were recorded: Plant height, Number of branches plant ${ }^{-1}$, Plant fresh and dry weight, and leaf area plant ${ }^{-1}$

\section{Green pods yield and its components:}

At harvesting time plants of the second row was allocated to measure the following data: number of green pods plant ${ }^{-1}$ and green pods yield ha. ${ }^{-1}$

\section{Chemical analysis of leaves:}

Wet digestion was performed on leaves according to Chapman and Pratt (1978). Molybdenum concentration $(\mu \mathrm{g} / \mathrm{g}$ dry wt.) was estimated by using Atomic Absorption Spectrophotometer according to Villora, et al. (2002). Total Nitrogen was determined using micro- kjeldahl method according to Ling (1963).

\section{Statistical analysis}

The obtained data were statistically analyzed using SAS Software program (1996). Comparisons among the means of different treatments were conducted using the Least Significant Difference Procedure at $\mathrm{P}=0.05$ level as illustrated by Al-Rawy and Khalf-Allah (1980).

\section{RESULTS AND DISCUSSION}

\section{The main effects of Rhizobium, nitrogen and molybdenum}

Tables (1and 4) showed that Rhizobium inoculation treatments significantly, increased all the vegetative growth of bean plants in both seasons compared to uninoculated control. Meanwhile, branch number in the first season and plant height in the second season reflected a similar trend though the differences were insignificant. Rhizobium inoculation significantly increased plant fresh and dry weights and green pods yield by $9.45,6.27$ and $15.37 \% ; 15.17,7.23$ and 19.7 $\%$ in the first and second seasons respectively. The beneficial effects of these bacteria have been attributed to their ability to produce various compounds including phytohormones, organic acids and fixation of atmospheric nitrogen (Lazarovits and Nowak, 1997 and Noel et al., 1996). These findings agree with the results of Solaiman and Khondaker (2002) who reported that peas green pods yield increased by $111 \%$ over uninoculated control when plants were inoculated with Rhizobium strains. Kanaujia et al. (1998) obtained similar result with pea crop. Also it can be noticed from the data of Table(4) that Rhizobium inoculation significantly increased $\mathrm{N}$ and Mo contents of leaves as compared to the control in both seasons. This inspection was confirmed by Moawad et al. (2004), who mentioned that Rhizobia inoculation showed a positive response due to enhanced plant growth and $\mathrm{N}$ values compared to control.

Nitrogen application rates (Tables1 and 4) had significant effects on the plant height, number of branches, plant fresh and dry weight, and number of green pods as well as green pods yield in the two growing seasons compared to the control treatment. Increasing nitrogen levels up to $96 \mathrm{~kg} \mathrm{~N}^{-1}$ reflected positive effects on vegetative growth characters and green pods yield. Nitrogen treatments of 48 and $96 \mathrm{Kg}$ $\mathrm{Nha}^{-1}$ increased leaves area by 17.11 and $31.65 ; 21.73$ and $33.47 \%$ whereas green pods yield increased by 61 .91 and $97.3 ; 60.27$ and $106.4 \%$ over the control in the first and the second seasons respectively. The obtained results are in accord with those of Arisha and Bardisi (1999) who reported that the number and yield of green pods plant ${ }^{-1}$ as well as the total green pods yield were significantly increased with increasing the applied nitrogen up to $192 \mathrm{~kg} \mathrm{~N} \mathrm{ha}^{-1}$. Ismail (2002) indicated that addition of $216 \mathrm{Kg} \mathrm{N} \mathrm{ha}^{-1}$, to the growing pea 
Elkhatib, H.A.: Growth and Yield of Common Bean (Phaseolus Vulgaris L.) in Response to Rhizobium Inoculation, Nitrogen ...

plants, was sufficient for the plants to express their best performance on the green pods yield and its components. Similar trends were reported by several researchers such as Solieman et al. (2003), and gabr et al (2007) on pea plants. 



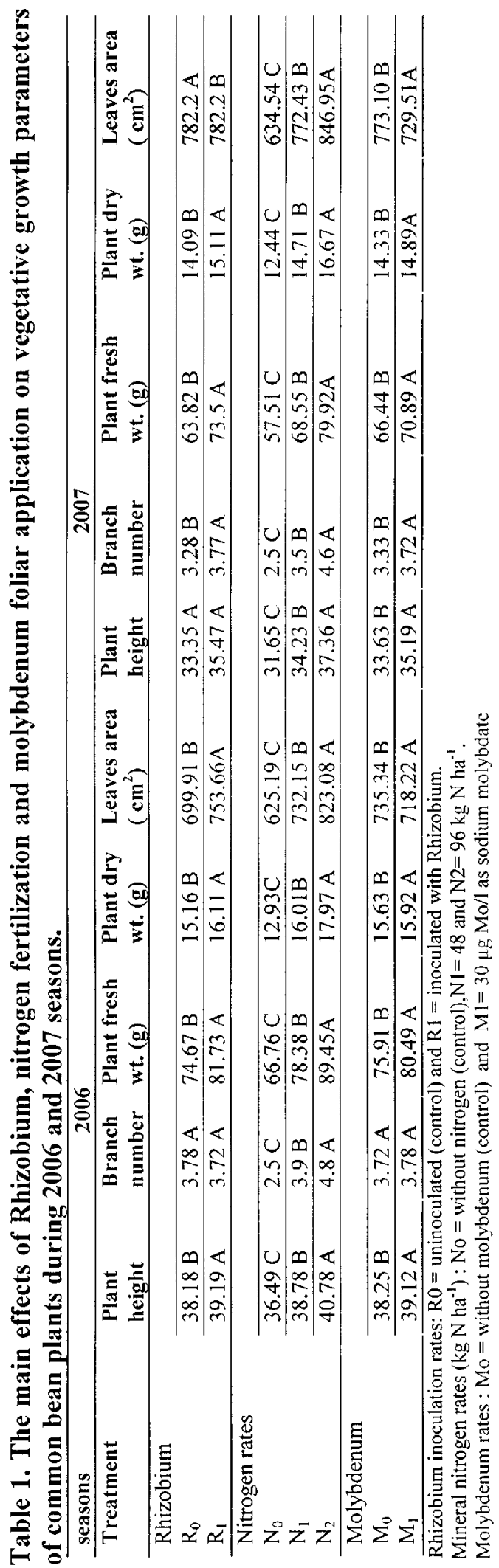




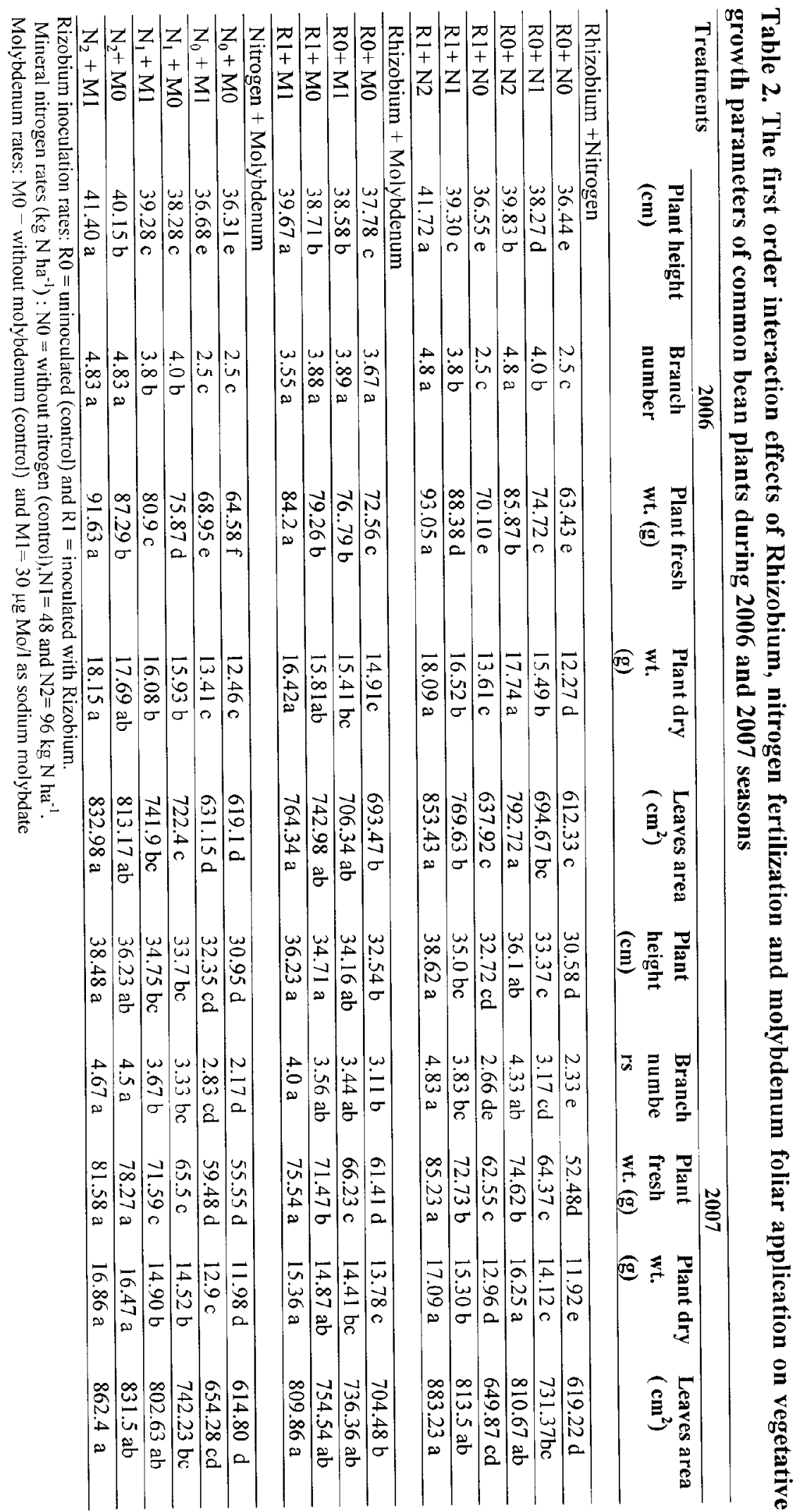




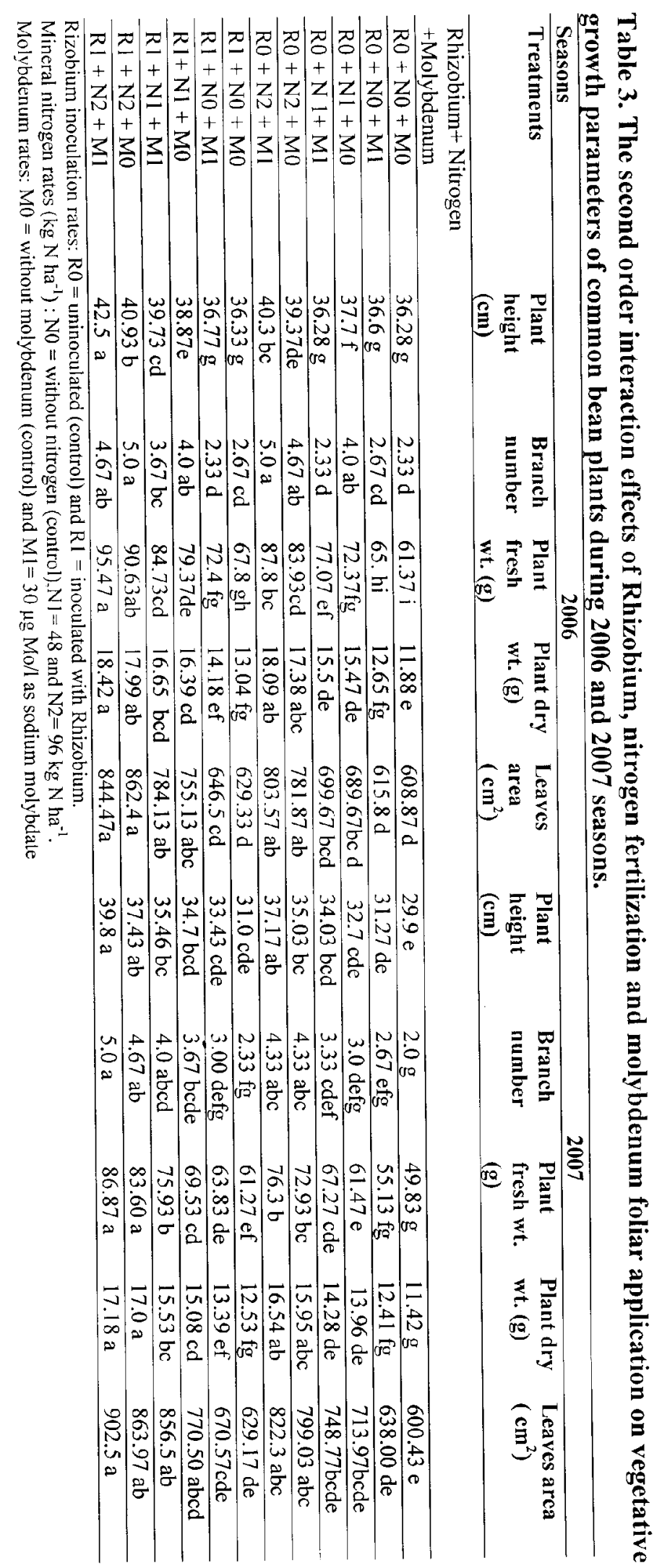




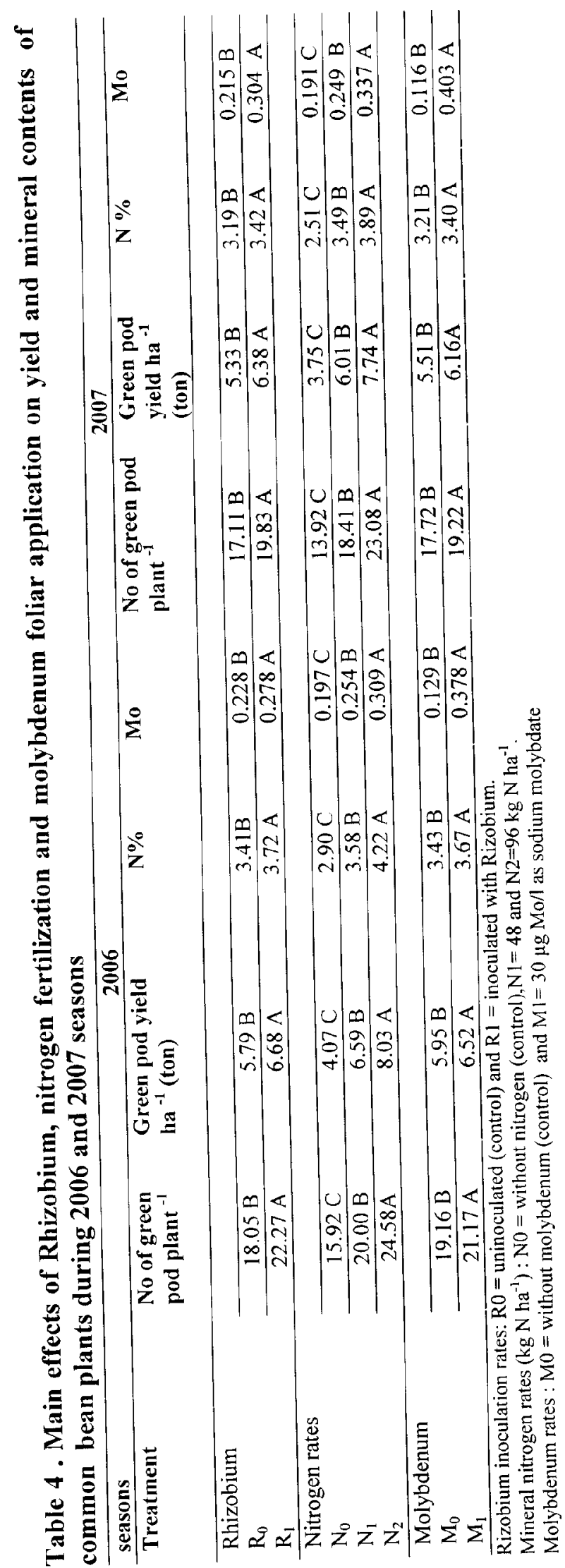


Molybdenum treatment (Tables 1 and 4) significantly increased all the studied vegetative growth characters and green pods yield of common bean plants in both years of investigations. Treated common bean plants with molybdenum achieved higher plant fresh and green pods yield by 6.03and 9.57; and 6.69 and $11.79 \%$ compared to the control in the first and the second seasons respectively. Similar results were reported by Chahal and Chahal (1991), who treated pea with molybdenum $(30 \mu \mathrm{g} / \mathrm{l})$ and achieved significantly higher yields of dry matter compared to untreated plants. On the other hand Mo foliar application significantly increased leaves $\mathrm{N}$ and Mo contents in both seasons .The higher Mo contents in bean plants with Mo application are similar to that reported for groundnut and soybean (Gupta, 1997)

First order Interactions of Rhizobium, Nitrogen and Molybdenum

\section{1-Interaction effects between Rhizobium and nitrogen}

The data presented in Tables (2 and 5) reflect the effects of the first degree interaction between Rhizobium and nitrogen fertilization levels, on vegetative growth characters, green pods yield and leaves $\mathrm{N}$ and Mo contents of common bean plants in the two growing seasons. The results of the two seasons indicated that the means of all studied characters increased significantly within the treatment combinations involving seed inoculation comparing with uninoculated treatment. Soil application of $\mathrm{N}$ at the rate of $96 \mathrm{~kg} \mathrm{~N} \mathrm{ha}{ }^{-1}$ to the inoculated seeds produced the best interaction effect among the different combination for all the studied characters in both seasons. These data are in accordance with those of Ishaq (2002) who reported that inoculation pea seeds with the biofertilizers and $\mathrm{N}$ application attained the best results on plant height, fresh and dry weight plant ${ }^{-1}$ and dry matter content of leaves and stems. Also the present results agreed to a great extent, with those reported by Merghany (1999) who reported that fresh and dry weight of snap bean increased with increasing $\mathrm{N}$ fertilization up to the rate of $216 \mathrm{~kg} \mathrm{Nha}^{-1}$. Chetti et al. (1995) studied the effect of nitrogen and Rhizobium inoculation on the productivity of groundnut genotype and reported that both nitrogen application and inoculation had significant positive effects on groundnut yield. Kelner et al. (1997) and Lamb et al. (1995) reported that forage legumes have a high capacity to fix $\mathrm{N}$ even if high levels of mineral $\mathrm{N}$ are available in the soil. With respect to $\mathrm{N}$ and Mo contents of leaves of common bean (Table 5) data indicated that raising applied $\mathrm{N}$ levels to $96 \mathrm{~kg} \mathrm{~N}^{-1}$ significantly increased leaves $\mathrm{N}$ and Mo contents over that of the control treatments.

\section{2-Interaction effects between Rhizobium and molybdenum}

The combined interaction of Molybdenum and Rhizobium inoculation and its influence on vegetative growth characters and green mass yield of common bean plants in the two growing seasons are shown in Tables ( 2 and 5 ). The differences occurred between the various treatments are statistically significant in both seasons. The combined effect of Rhizobium inoculation in the presence of molybdenum revealed the highest value in both seasons. Rizobium inoculation with Mo leaf spray caused a positive effect on the most of vegetative growth characters, green pods yield and leaves nitrogen and molybdenum contents in both seasons. The inoculated treatments and Mo fertilization increased Plant fresh weight and pods green yield by 16.04 and $26.16 \%$; and 23.0 and $45.86 \%$ in the first and second seasons respectively. Similar results were obtained by Yanni (1992) who reported that the seed yield of Rhizobium inoculated legume crops is increased strikingly by Mo fertilization. The role of Mo as a plant nutrient is related to its function as a metal component of some enzymes that catalyze nitrogen fixation, nitrate assimilation and reduction (Svetsov et al., 1992). A recent study by Hristozkova et al. (2007) established that foliar application of nutrients on pea reduced the inhibitory effect on the root nodulation and nitrogen assimilator enzyme activities due to molybdenum shortage when plants were inoculated with Rhizobium.

\section{3- Interaction effects between nitrogen and molybdenum}

The comparisons among the means of various treatment combinations of molybdenum treatments and the nitrogen fertilization levels on vegetative growth characters and green pods yield and leaves nitrongen and molybdenum contents of common bean plants are illustrated in Tables ( 2 and 5). The results of the two seasons indicated that the highest mean values of all studied characters were obtained from the bean plants that were fertilized with nitrogen at the rate of $96 \mathrm{~kg} \mathrm{~N}$ $\mathrm{ha}^{-1}$ and sprayed with molybdenum. Plant fresh and dry weights and green bean yield increased by $41.88,45.66$ and $120.48 \%$; and $46.86,40.73$ and $134.59 \%$ of the control in the first and the second season respectively. Berger et al. (1996) found that the Mo foliar applied dosage of $78 \mathrm{~g} \mathrm{ha}^{-1}$ provided an increase in yield by $163 \%$ when compared with control. Also Maurya et al. (1993) reported that $\mathrm{N}$ uptake increased with Mo application in black gram and Mo application positively 
affected plant $\mathrm{N}$-yield in noninoculated or inoculated plants. Mendel and Hansch(2002) reported that the stimulatory effect of Mo application could be due to the increase of the metabolic pools required for the synthesis of saccharides, along with the enhanced photosynthetic capacity.

\section{Second order Interactions of Rhizobium, Nitrogen and Molybdenum}

The second order interactions among all studied factors showed that different studied parameters of vegetative growth, green pods yield and leaves nitrogen and molybdenum contents of common bean plants are significantly affected (Tables 3 and 6). The best treatment combinations that involved seed inoculation, molybdenum foliar application and nitrogen fertilization at the rate of $96 \mathrm{~kg} \mathrm{~N}^{-1}$ gave the highest mean values of green pods yield, plant fresh and dry weights and $\mathrm{N}$ and Mo contents. The obtained results are in agreement with those presented by Krishnasamy et al. (1985) who reported that molybdenum and nitrogen application significantly increased grain and straw yields of cowpea. Gungula and Garjila (2006) also reported that molybdenum application has been found to significantly increase pods yield of cow pea. On the other hand, Waterer et al. (1992) found that peas plants grown in the presence of $\mathrm{NH}_{4}$ fixed as much or more $\mathrm{N}_{2}$ than the plants supplied with minus $-\mathrm{NH}_{4}{ }^{+}$nutrient solution.

\section{Polynomial Quadratic Models.}

The polynomial quadratic model was used to describe bean yield response to nitrogen increments under molybdenum fertilization and Rizobium inoculation in two successive summer growing seasons. The polynomial quadratic model used in the form:

$\mathrm{Y}_{\mathrm{i}}=\mathrm{B}_{0}+\mathrm{B}_{1} \mathrm{X}_{\mathrm{i}} \pm \mathrm{B}_{2} \mathrm{X}_{\mathrm{i}}^{2}$

Where: $Y_{i}$ is the expected yield corresponding to nutrient rate $\mathrm{X}_{i} \mathrm{~B}_{0}$ is the intercept, and $\mathrm{B}_{1}$ and $\mathrm{B}_{2}$ are the linear and quadratic coefficients, respectively.

The method of the least squares using the experimental results was used to calculate the values of $\mathrm{B}_{0}, \mathrm{~B}_{1}$ and $\mathrm{B}_{2}$ in the polynomial model. Thus 4 polynomial quadratic models were established to express the relationship between green pods yield and application rate of $\mathrm{N}$ fertilizer under Molybdenum fertilization and Rhizobium inoculation for each season (Table 7 and Figs $1 \& 2$ ).

The calculated yields in the two seasons closely approximate experimental yields as shown from the highly significant value of determination coefficients (Figs. 3 and 4). Therefore it can be concluded that the effect of nitrogen application, Rhizobium inoculation and molybdenum fertilization on increasing green pods yield could be successfully predicted by using polynomial quadratic equations.

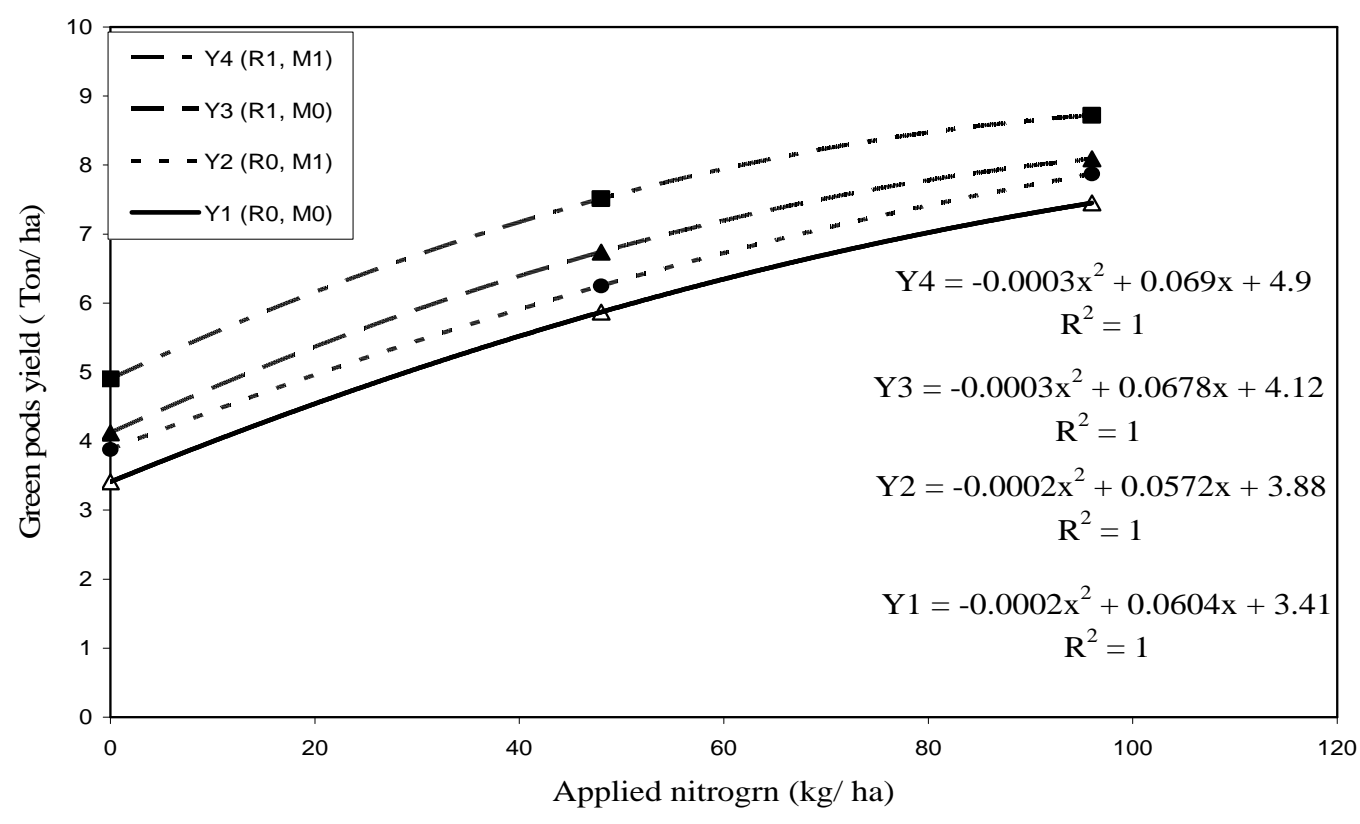


Fig. 1. Green pods yield response curve of common bean cultivar (Giza 3) to nitrogen fertilization Rhizobium inoculation and molybdenum foliar application during the season of 2006

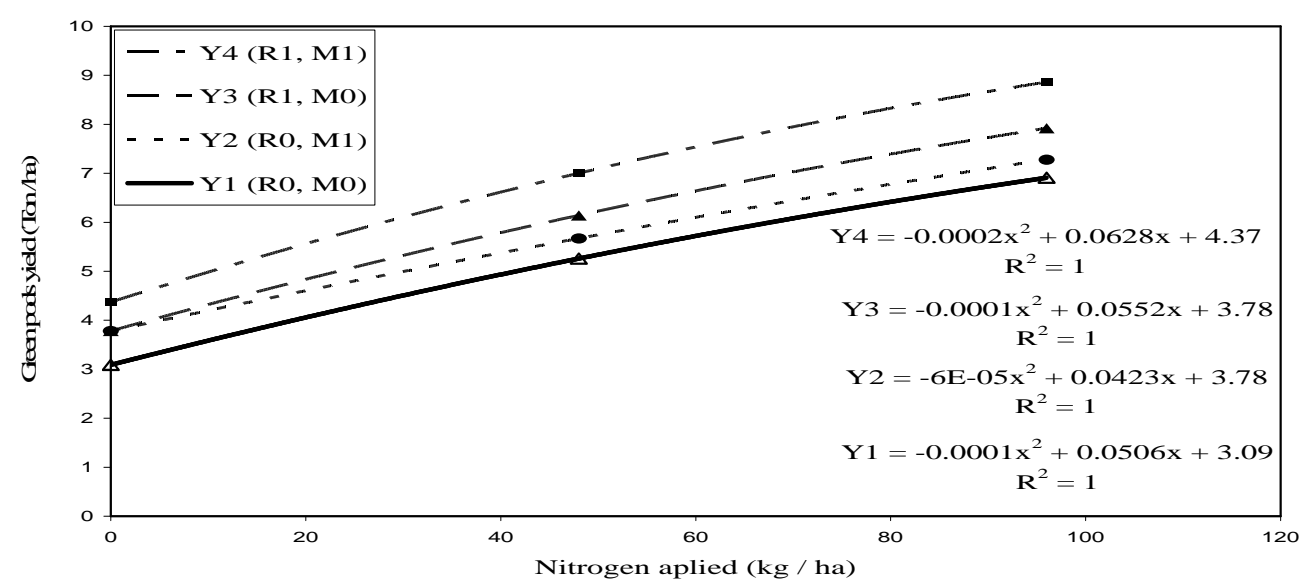

Fig. 2. Green yield response curve of common bean cultivar (Giza 3) to nitrogen fertilization, Rhizobium inoculation and molybdenum forliar application during the season of 2007

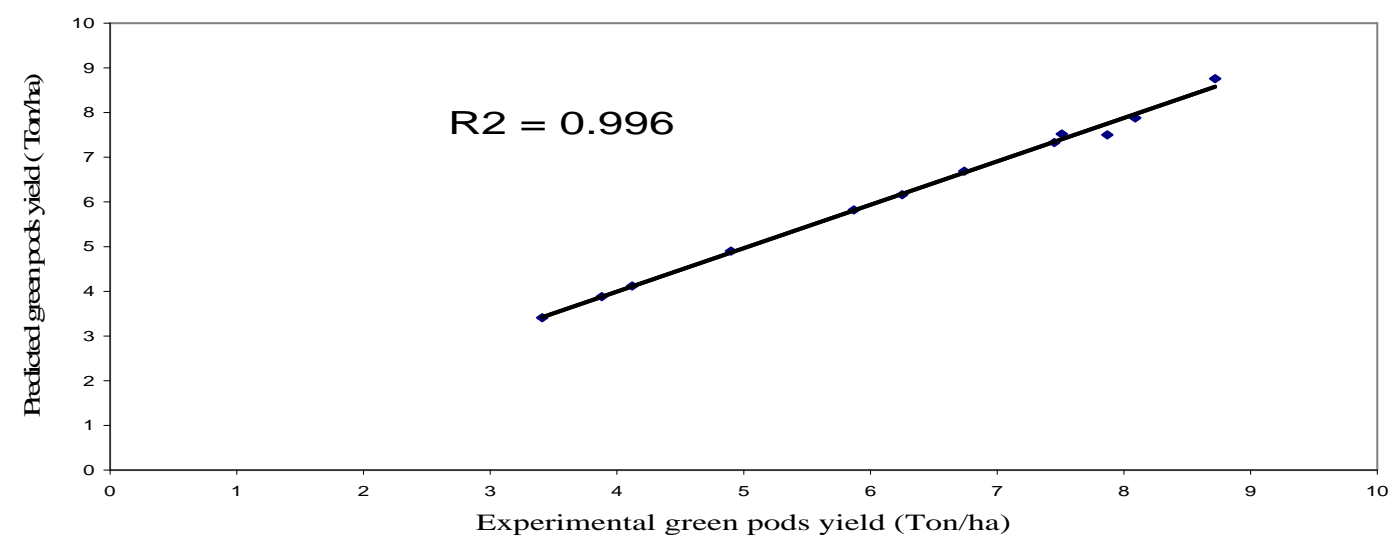

Fig. 3. Correlation between exeperimental and predicated green pods yield of common beans as affected by nitrogen fertilization Rhizobium incolation and molybdnum foliar application during the season of 2006

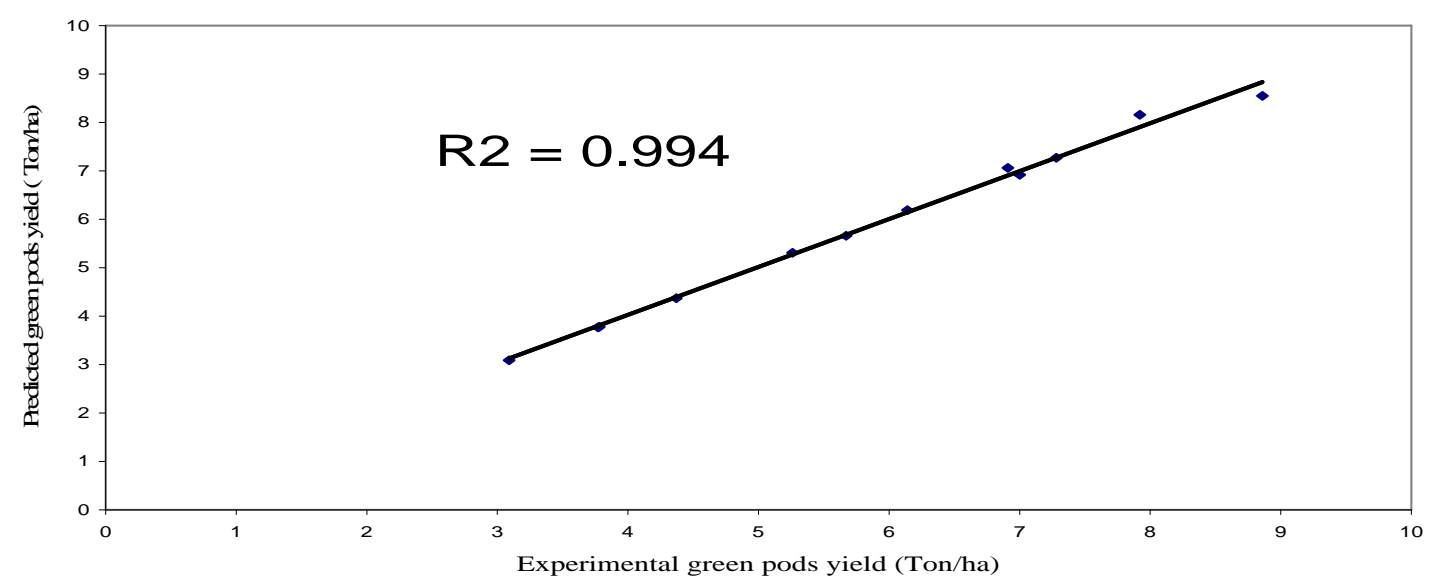


Fig. 4. Correlation between exeperimental and predicated green pods yield of common beans as affected by nitrogen fertilization, Rhizobium incolation and molybdnum foliar application during the season of 2007 


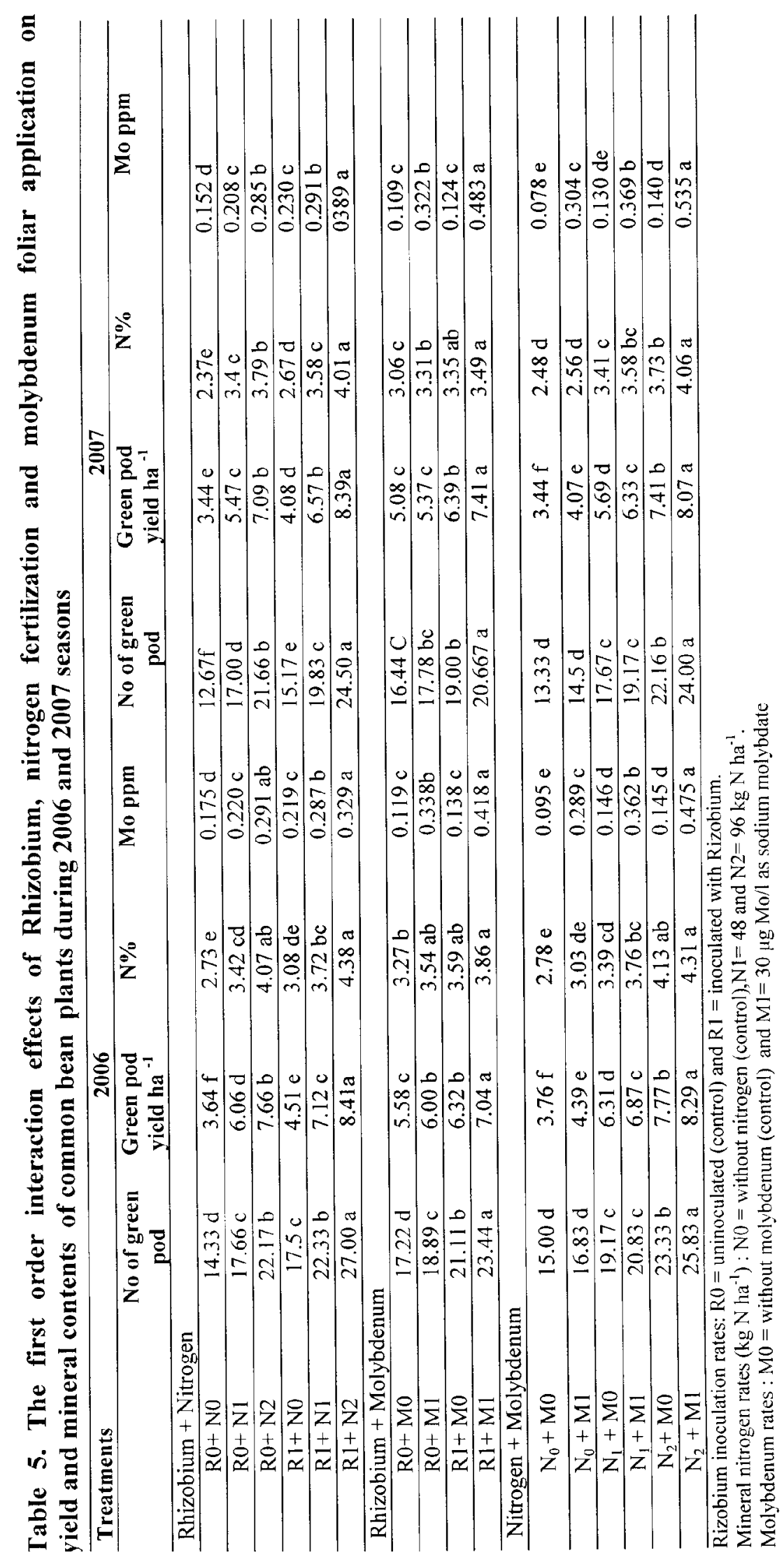




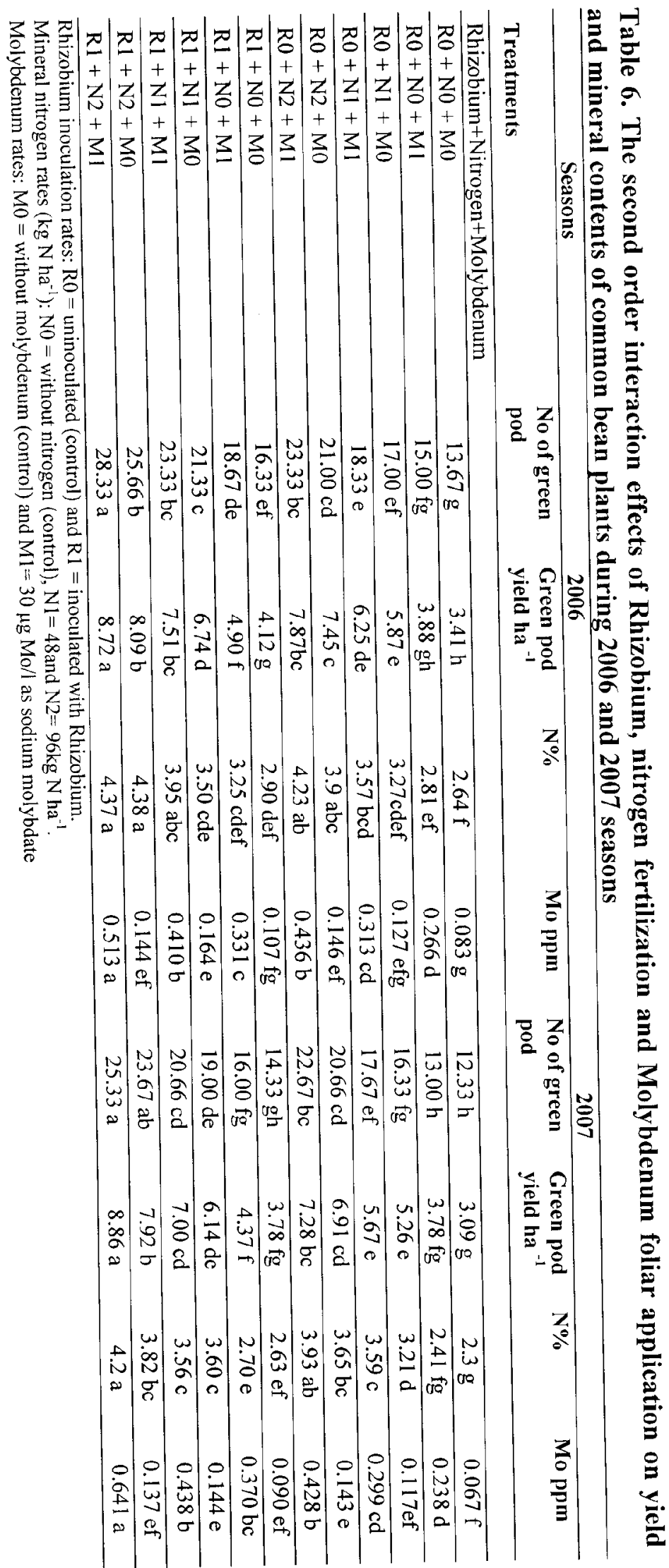


Table 7. The polynomial quadratic equations expressing beans green pods yield as affected by $\mathbf{N}$ fertilization, Rhizobium inoculation and Molybdenum application

\begin{tabular}{ccc}
\hline Treatment & Polynomial Quadratic Equations \\
\hline & Season 2006 & \\
\hline $\mathrm{R}_{0} \mathrm{M}_{0}$ & $\mathrm{Y} 1=3.41+0.060 \mathrm{x}-0.0002 \mathrm{x}^{2}$ & $(2)$ \\
$\mathrm{R}_{0} \mathrm{M}_{1}$ & $\mathrm{Y} 2=3.88+0.057 \mathrm{x}-0.0002 \mathrm{x}^{2}$ & $(3)$ \\
$\mathrm{R}_{1} \mathrm{M}_{0}$ & $\mathrm{Y} 3=4.12+0.068 \mathrm{x}-0.0003 \mathrm{x}^{2}$ & $(4)$ \\
$\mathrm{R}_{1} \mathrm{M}_{1}$ & $\mathrm{Y} 4=4.9+0.069 \mathrm{x}-0.0003 \mathrm{x}^{2}$ & $(5)$ \\
\hline & Season 2007 & \\
\hline $\mathrm{R}_{0} \mathrm{M}_{0}$ & $\mathrm{Y} 1=3.09+0.0506 \mathrm{x}-0.0001 \mathrm{x}^{2}$ & $(6)$ \\
$\mathrm{R}_{0} \mathrm{M}_{1}$ & $\mathrm{Y} 2=3.78+0.0423 \mathrm{x}-6 \mathrm{E}-05 \mathrm{x}^{2}$ & $(7)$ \\
$\mathrm{R}_{1} \mathrm{M}_{0}$ & $\mathrm{Y} 3=3.78+0.0552 \mathrm{x}-0.0001 \mathrm{x}^{2}$ & $(8)$ \\
$\mathrm{R}_{1} \mathrm{M}_{1}$ & $\mathrm{Y} 4=4.37+0.0628 \mathrm{x}-0.0002 \mathrm{x}^{2}$ & $(9)$ \\
\hline
\end{tabular}

$\mathrm{R}_{0} \mathrm{M}_{0}=$ - Rhizobium inoculation and - molybdenum fertilization

$\mathrm{R}_{0} \mathrm{M}_{1}=$ - Rhizobium inoculation. and + molybdenum fertilization

$\mathrm{R}_{1} \mathrm{M}_{0}=+$ Rhizobium inoculation and - molybdenum fertilization

$\mathrm{R}_{1} \mathrm{M}_{1}=+$ Rhizobium inoculation and + molybdenum fertilization

\section{REFERENCES}

Al-Rawy, K.M. and A.M. Khalf-Allah. (1980). Design and Analysis of Agricultural Experiments. Text book. ElMousil Univ. press Ninawa, Iraq. pp.487.

Arisha, H.M. and A. Bardisi.(1999).Effect of nitrogen fertilization and plant spacing on growth, yield and pod quality of common bean under sandy soil conditions. Zagazig J. Agric. Res. 26 (2): 407 - 419.

Berger, P. G., C. Vieira, and G. A. A. Ara'ujo. (1996). Effects of rates and date of molybdenum application on common beans. Pesquisa Agropecu'aria Brasileira 31: 473-490.

Brar, J.S. and P.B. Lal., (1991). Effect of Rhizobium inoculation, phosphorous and molybdenum on yield and its components in Mungbean. Ind. Agriculturist, 35: 6769.

Chahal V.P.S.and Chahal P.P.K. (1991): Interaction studies between Rhizobium leguminosarum and Meloidogyne incognita on pea (Pisum sativum L.) growth under different concentrations of molybdenum. Plant Soil Sci., 45: 673-676.

Chapman, H. D and P. f. pratt. (1978). Methods of Analysis for Soils, Plants and Waters. Division of Agriculture Sciences, University of California, Davis, pp 50.

Chetti, M.B., E. Antony, U.V. Mummigatti and M.B. Dodammi., (1995). Role of nitrogen and rhizobium on nitrogen utilization efficiency and productivity potential in groundnut genotypes. Farming Systems, 11: 25-33

Consideine, M., (1992). Effect of Urea on photosynthesis and yield in Mungbean. J. Agron. Crop. Sci., 168: 91- 94.

FAO Statistics, (2007). Production Yearbook 2007,

Gabr, S.M., H.A. Elkhatib, and A.M. El-Keriawy. (2007). Effect of different biofertilizer types and nitrogen fertilizer levels on growth, yield and chemical contents, of pea plants (Pisum sativum L.). J. Adv. Agric. Res. 6 (4):939-955.
Gungula 'D.T. and Y. Garjila. (2006). The effects of molybdenum application on growth and yield of cowpea . American-Eurasian J. Agrie. \& Environ. Sci., 1 (2): 96101.

Gupta, U.C., (1997). Molybdenum in Agriculture. Cambridge University Press, UK.

Hristozkova, M., M. Geneva, I. Stancheva an G. geogiev. (2007) . Response of inoculated pea plants to reduce Mo supply .Acta Biologica Hungarica ,58:87-92.

Ishaq, M. S. (2002).Comparisons among the effect of biofertilizer, nitrogen and boron on growth, seed production and seed quality of peas (Pisum sativum L.).Ph.D.Thesis, Fac. Agric., Alex. Univ. Egypt.

Ismail, R .H. (2002).Physiological studies on biofertilization in pea plants (Pisum sativum L.) under calcareous soil conditions .Ph. D. Thesis, Fac. Agric., Ain Shams. Univ. Egypt.

Jongruaysup S., Ohara G.W., Dell B., Bell R.W. (1993): Effects of low molybdenum seed on nodule initiation, development and $\mathrm{N}_{2}$ fixation in black gran (Vigna mungo L). Plant Soil, 156: 345 - 348.

Kanaujia, S. P., S. K. Sharma and K. B. Rastogi. (1998). Effect of phosphorus, potassium and Rhizobium inoculation on growth and yield of pea (Pisum sativum L.). Annals of Agric. Res. 19(2): 219-221.

Kelner, D.J., J.K. Vessey, and M.H. Entz. (1997). The nitrogen dynamics of 1-,2- and 3-year stands of alfalfa in a cropping system. Agric. Ecosyst. Environ. 64:1-10.

Krishnasamy, R., T.S. Manikam and G.V. Kothandaraman. 1985. Influence of phosphorous and micronutrient on yield and uptake of NPK in cowpea. Madras Agric. J., 72: $181-184$.

Lamb, J.F.S., D.K. Barnes, M.P. Russelle, C.P. Vance, G.H. Heichel, and K.I. Henjum. (1995). Ineffectively and effectively nodulated alfalfas demonstrate biological 
nitrogen fixation continues with high nitrogen fertilization. Crop Sci.35:153-157.

Lazarovits,G. and J. Nowak. (1997). Rhisobacteria for improvement of plant growth and stablishment. Hort. Sci. 32(2): 188-192.

Ling, E.R. (1963). Determination of total nitrogen by semimicro Kjeldahl method. Dairy Chem., 11: 23-84.

Marschner, H. (1995): Mineral nutrition of higher plants, $2^{\text {nd }}$ edition. Academic press, New York,

Maurya, B.R., K. Kishor and P.C. Ram. (1993). Effects of iron and molybdenum on soybean. J. Maharastra Agri. Univ. 18(1): 128.

Mendel, R., and R. Haensch, (2002). Molybdoenzymes and molybdenum cofactor in plants, J. Exp.Botany, 53, 16891698.

Merghany, M.M. (1999).Response of snap bean to different Rhizobium inoculation methods and nitrogen levels under two drip irrigation regimes in new reclaimed sandy soil. Zagazig J. Agric. Res. 26(4): 1091 - 1123.

Moawad, H., W.M. Abd El-Rahim and D. Abd El-Haleem, (2004). Performance of phaseolus bean rhizobia in soils from the major production sites in the Nile Delta. C.R. Biologies, 327: 445-453.

Noel, T. C.; C. Sheng, C.K.Yost, R. P. pharis and M. E. Hynes. (1996). Rhizobium leguminosarum as a plant growth Promoting rhizobacterium: direct growth promotion of canola and lettuce. Can. J. Microbiol, 42(3): 270-283.

Page, A.L.,R.H. Miller and D.R Keeneny. (1982). Methods of soil analysis. Part 2. chemical and microbiological properties. $2^{\text {nd }}$ edition. Agron .Madison, Wisconsin ,USA.
SAS. (1996). Software program. Cary, North Carolina State. Univ., Karl M Glsener. USA.

Solaiman, A. R. M. and M. Khondaker. (2002). Responses of some pea varieties to Rhizobium inoculation, Yield attributes, yield and nutrient content in seed. Bangladesh J. Microbiol. 19(1-2): 41-46.

Solieman, T. H., H. A. ElKhatib and S. M. El-Araby. (2003). Effects of organic manure, mineral nitrogen and biofertilizer application on vegetative growth and chemical composition of pea (Pisum sativum, L.). Zagazig J. Agric. Res. 30 (3): 751-767

Srivastava, T. K., I. P. S. Ahlawat and J. D. S. Panwar. (1998). Effect of phosphorus, molybdenum and biofertilizers on productivity of pea (Pisum sativum L.). Ind. J. Plant Phyiol. 3(3): 237-239.

Svetsov, A.A, A.V Amelin, N.V. Novikova and N.P. Lvov, (1992). The molybdenum cofactor of pea seeds. Sov. Plant Physiol., 39: 104-109.

Thakur, A.K. and J.D.S. Panwar, (1995). Effect of Rhizobium VAM interactions on growth and yield in Mungbean. Indian J. P. Physiol., 38: 62-65.

Villora, G., Moreno, D. A.,Romero, L. (2002). Response of eggplant to nitrogen supply molybdenum-nitrate relationships: Biologia Plantarum 45(4): 621-623

Waterer J.G., J.K. Vessey and C.D. Raper (1992): Stimulation of nodulation in field peas (Pisum sativum) by low concentrations of ammonium in hydroponic culture. Physiol. Plant., 86: 215-220.

Yanni, Y.G. (1992) Performance of chickpea, lentil and lupin nodulated with indigenous or inoculated rhizobia, boron, cobalt, and molybdenum fertilization schedules. World J. Microbiol. Biotech., 8: 607-613. 


\section{الملخص العربي}

\section{تأثير التسميد بالنتروجين والموليبدنم مع التلقيح بالر ايزوبيم على النمو والخصول للفاصوليا}

حسن احمد الخطيب

النيتروجين الموليبدنم وأوضحت النتائج أن إضافة السماد النيتروجيني

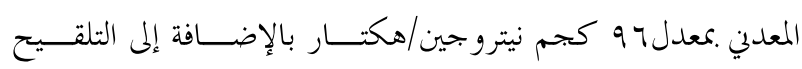

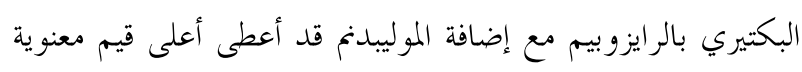

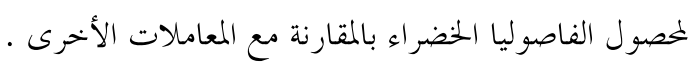

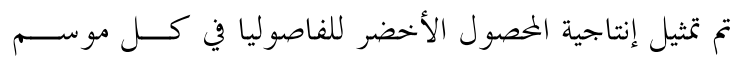

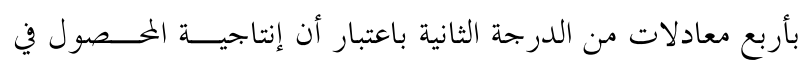

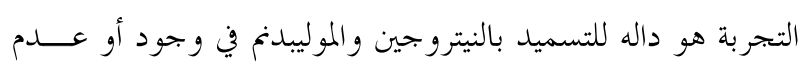

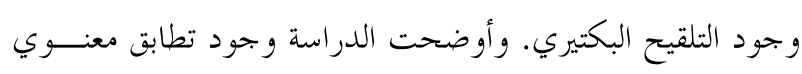

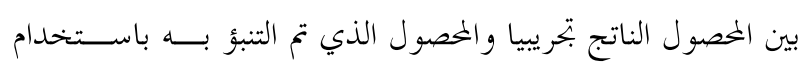
المعادلات وذلك لكل المعاملات تحت الدراسة.

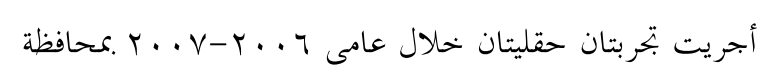
البحيرة كلية الزراعة وذلك لدراسة مدى استجابة محصول الفاصوليا الخضراء "صنف جيزة ب" للتلقيح الحيوي للبذور بالرايزوبيم(تلقيح

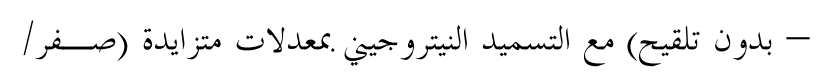

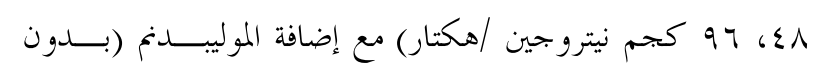

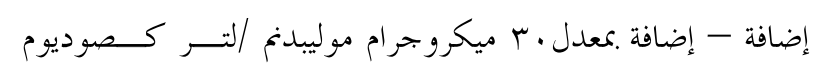

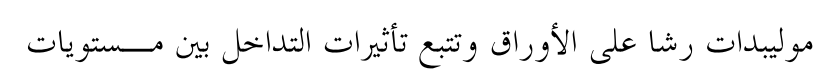

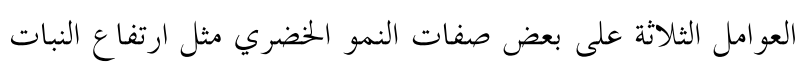

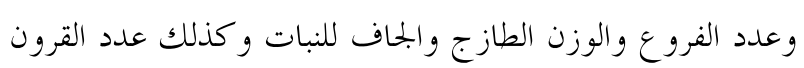

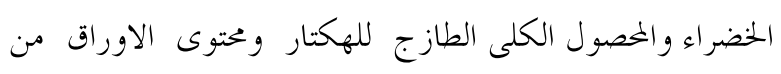

